\title{
A Comparison of Epithelial Cells, Fibroblasts, and Osteoblasts in Dental Implant Titanium Topographies
}

\author{
Fu-Yuan Teng, ${ }^{1,2}$ Chia-Ling Ko, ${ }^{2}$ Hsien-Nan Kuo, ${ }^{3}$ Jin-Jia Hu, ${ }^{4}$ \\ Jia-Horng Lin, ${ }^{5}$ Ching-Wen Lou, ${ }^{6}$ Chun-Cheng Hung, ${ }^{2}$ Yin-Lai Wang, \\ Cheng-Yi Cheng, ${ }^{2}$ and Wen-Cheng $\mathrm{Chen}^{7}$ \\ ${ }^{1}$ Department of Dentistry, Kaohsiung Armed Forces General Hospital, Kaohsiung 802, Taiwan \\ ${ }^{2}$ School of Dentistry, College of Dental Medicine, Kaohsiung Medical University, Kaohsiung 807, Taiwan \\ ${ }^{3}$ Medical Device Development Division, Metal Industries Research \& Development Centre, Kaohsiung 82151, Taiwan \\ ${ }^{4}$ Department of Biomedical Engineering, National Cheng Kung University, Tainan 701, Taiwan \\ ${ }^{5}$ Laboratory of Fiber Application and Manufacturing, Department of Fiber and Composite Materials, Feng Chia University, \\ School of Chinese Medicine, China Medical University, Taichung 40724, Taiwan \\ ${ }^{6}$ Institute of Biomedical Engineering and Material Science, Central Taiwan University of Science and Technology, \\ Taichung 40601, Taiwan \\ ${ }^{7}$ Department of Fiber and Composite Materials, College of Engineering, Feng Chia University, 100 Wenhwa Road., Seatwen, \\ Taichung 40724, Taiwan
}

Correspondence should be addressed to Wen-Cheng Chen, chernlin2@gmail.com

Received 12 July 2011; Accepted 28 September 2011

Academic Editor: Ivano Bertini

Copyright (c) 2012 Fu-Yuan Teng et al. This is an open access article distributed under the Creative Commons Attribution License, which permits unrestricted use, distribution, and reproduction in any medium, provided the original work is properly cited.

\begin{abstract}
The major challenge for dental implants is achieving optimal esthetic appearance and a concept to fulfill this criterion is evaluated. The key to an esthetically pleasing appearance lies in the properly manage the soft tissue profile around dental implants. A novel implant restoration technique on the surface was proposed as a way to augment both soft- and hard-tissue profiles at potential implant sites. Different levels of roughness can be attained by sandblasting and acid etching, and a tetracalcium phosphate was used to supply the ions. In particular, the early stage attaching and repopulating abilities of bone cell osteoblasts (MC3T3-E1), fibroblasts (NIH 3T3), and epithelial cells (XB-2) were evaluated. The results showed that XB-2 cell adhesive qualities of a smooth surface were better than those of the roughened surfaces, the proliferative properties were reversed. The effects of roughness on the characteristics of 3T3 cells were opposite to the result for XB-2 cells. E1 proliferative ability did not differ with any statistical significance. These results suggest that a rougher surface which provided calcium and phosphate ions have the ability to enhance the proliferation of osteoblast and the inhibition of fibroblast growth that enhance implant success ratios.
\end{abstract}

\section{Introduction}

Successful dental implant treatment depends on three components: bone, connective tissue, and epithelium. Each plays an important function; for example, connective tissue cannot anchor the implant surface having mechanical attachments as bone does because inadequate peri-implant epithelium function can lead to the creation of deep pockets and invasion of bacteria [1-3]. In addition, the fundamental esthetic outcomes associated with dental implant treatments are related to the healing characteristics of both the epithelium and connective tissue [4]. Different surface designs of materials can also cause varying levels of peri-implant hard and soft tissues $[4,5]$. Accordingly, the chemical composition and physical properties of the implant's surface can affect peri-implant tissues behavior $[6,7]$.

Many methods are used to create a rough implant surface. To create a three dimensional roughness on the implant surface for improving bone anchorage, differential ways such as titanium plasma spraying, grit or sandblasting, acidetching, and anodization were used [7-9]. Among these, a most popular way of the sandblasting and acid etching (SLA) have been reported. The SLA treatment showed the properties of earlier osseointegration and decreased bone loss than 


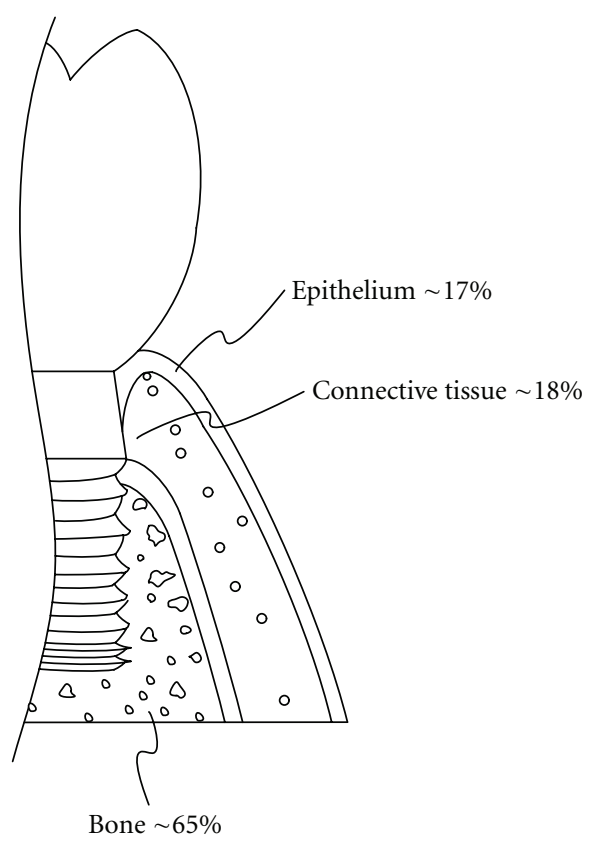

FIgURe 1: A diagrammatic illustration showing the relationship of the interfacial parts between periodontal tissues and an implant (length: $5.7 \mathrm{~mm}$ ). The relationship between the bone of the alveolar process, the gingival connective tissue and junctional epithelium are shown, at the level where the implants and tissues contact.

other surface treatment ways [10]. However, harmful metal ion dissolution and particles such as aluminum remain in the processes by SLA surface treating and lead to local or systemic toxic effects [11-13].

Peri-implant soft tissues play an important role, as they might encompass over one-third of the height area of short implants (Figure 1). After implantation, two distinct responses may occur on the implant surface. The bone tissue can contact the implant surface with a proper biological width, signaling a successful treatment with complete osseointegration. Another response is fibrous encapsulation involving the soft tissue covering the entire implant surface. These responses involve the three aforementioned cell types, which have distinct growth patterns and varying abilities of adhesion to the implant surface and the early stage attaching and repopulating abilities of cells is a common technique for evaluating initial stability of the implant [14-16].

Because implant surface treatment is usually only concerned with integration of bone tissues and neglects soft tissues, the surfaces contacting the implant and surrounding tissues deviates from the originally intended design leading to implantation failure. For this reason, current techniques are insufficient to achieve controlled success. Hence, the purpose of this study is to find the cells relationship to develop a proper tissue architecture on the pure Ti implant surfaces that is almost identical to the patient's original after tooth extraction and implantation. The process was to treat the different roughen surfaces, and then samples were cultured with bone cells, fibroblasts, and epidermal cells to evaluate the differential early stage cell attaching and repopulating abilities.

\section{Materials and Methods}

2.1. Materials_Surface Treatment. Commercially pure, grade II titanium (cp Ti) samples (Buehler Ltd, USA) measuring $6 \times 5 \times 1 \mathrm{~mm}$ in respective length, width, and thickness of constant surface areas of $30 \mathrm{~mm}^{2}$ within $2.5 \%$ standard deviation (SD) were used. The samples were embedded into an epoxy resin to be polished by sandpaper of decreasing grain sizes: 400, 1200 and 2000. Then the samples were washed following with ethanol, acetone, and distilled water using ultrasonic oscillation for each $5 \mathrm{~min}$. The Ti metal surface, a control group, controlled an Ra value of 0.12 micrometer $(\mu \mathrm{m})$ within $5.0 \%$ SD.

Testing groups, in which the surfaces of the control group were sandblasted for 10,20 , and $30 \mathrm{sec}$ with aluminum $\left(\mathrm{Al}_{2} \mathrm{O}_{3}\right)$ particles (mean size $\left.54.5 \pm 32.1 \mu \mathrm{m}\right)$. The sandblasting used an air compressor with $7 \mathrm{~kg} / \mathrm{m}^{2}$ of powder blasted over a $0.5 \mathrm{~mm}$ distance. After sandblasting, the samples were acid-etched for $30 \mathrm{sec}$. An etching solution of the $\mathrm{HCl}$ (37\%, Panreac, Barcelona, Spain) to $\mathrm{H}_{2} \mathrm{SO}_{4}$ (95-98\%, Panreac, Barcelona, Spain) to $\mathrm{H}_{2} \mathrm{O}$ volume ratio of $1: 1: 1$ was used. Testing groups were after different blasting times and following acid-etching processes (SLA) for constant time $30 \mathrm{sec}$ were presented as the symbols of 10/30,30/30, and $60 / 30$ groups $(n=10)$. To clarify the ion effect of $10 / 30$ testing group, a comparative group receiving secondary gritblasting using TTCP particles $(10 \mathrm{sec})$, which was prepared in-house and had a mean particle size of $10.1 \pm 0.7 \mu \mathrm{m}$ [17], was present as a SLA 10/30/TTCP group. The 10/30/TTCP group was dry-heat sterilized at $160^{\circ} \mathrm{C}$ for $2 \mathrm{~h}$ and the other samples were sterilized in an autoclave.

2.2. Surface Characterizations. The average surface roughness was measured using a roughness tester (SJ-301 Mitutoyo Ltd, Japan) and presented in Ra. Topographies and the anchored/residual particles were analyzed by a scanning electron microscope (SEM, Hitachi S-3000N, Japan) equipped with an energy dispersive X-ray spectrometer (EDS, Horiba EX220, Japan).

2.3. Cell Abilities and Morphologies. Three cell lines of the bone (MC3T3-E1, abbreviated E1), fibroblast (NIH 3T3, abbreviated 3T3), and epidermal (XB-2) cells were provided by the National Institute of Health (NIH) in Taiwan. E1 was derived from newborn mouse calvaria and were cultured in a $10 \mathrm{~mL}$ of alfa-modified Eagle's medium (MEM) containing 10\% fetal bovine serum (FBS) (Biological Industries, Haemek, Israel), and $1 \%$ penicillin (100 units/mL)/streptomycin $(100 \mu \mathrm{g} / \mathrm{mL}$ ) (Gibco, Invitrogen Taiwan Ltd., MD). 3T3 was derived from newborn mouse fibroblasts and cultured in Dulbecco's modified Eagle's medium (DMEM) (Gibco, Invitrogen Taiwan Ltd., MD) containing $10 \%$ bovine serum (BS) (Biological Industries, Haemek, Israel). XB-2 was derived from newborn mouse keratinized cells and cultured as in the study [18]. XB-2 cells 


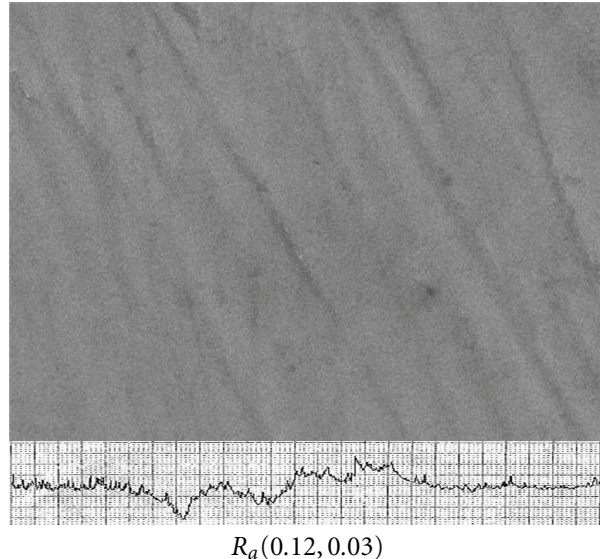

(a)

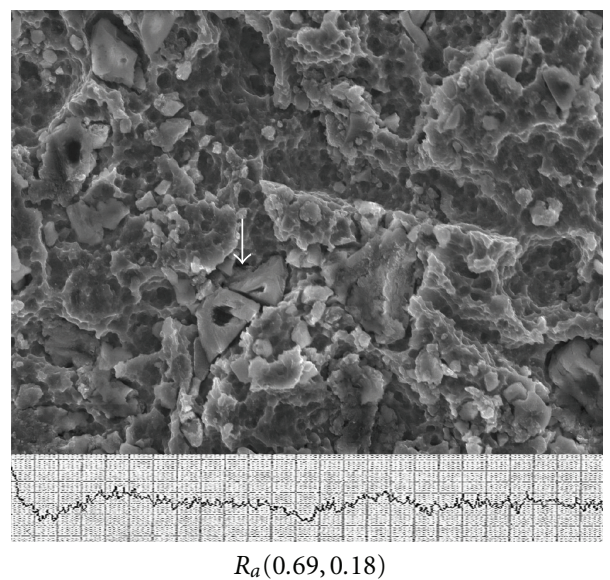

(c)

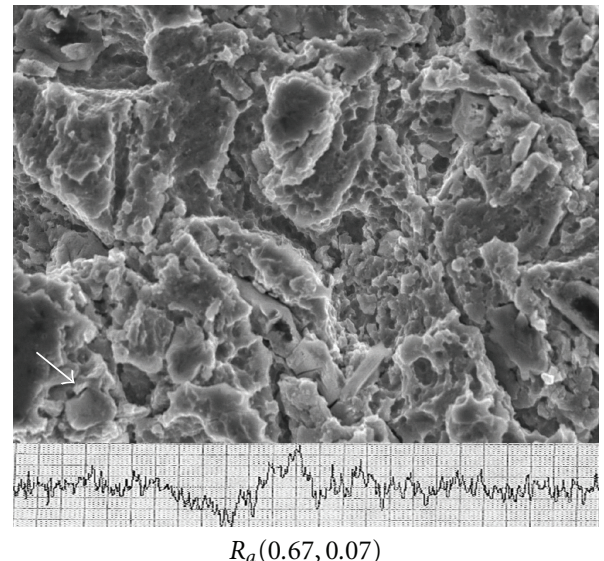

(b)

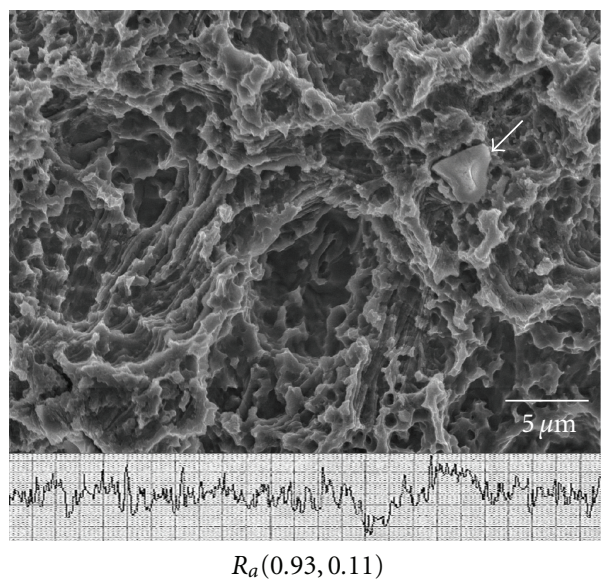

(d)

Figure 2: The different topographies of cp Ti surfaces and their respective levels of roughness after blasting/etching for various times (sec). (a) Control and (b) 10/30, (c) 30/30, (d) 60/30 test groups. Ra: average roughness (mean, SD), units: micrometers. Arrowhead: surfacetrapped alumina.

were grown in the presence of 3T3 cells, which were briefly cultured on a $0.1 \%$ gelatin-coated plate (G932-500G, Sigma Co., St. Louis, USA) before culturing in DMEM containing mitomycin C $(10 \mu \mathrm{g} / \mathrm{mL})$ for $2.5-3 \mathrm{~h}$. Subsequently, XB-2 cells were cultured in DMEM containing 20\% FBS. All cells were cultured in a humidified atmosphere in a $5 \% \mathrm{CO}_{2}$ incubator. The culture medium was replaced every 2-3 days. After the cultured cells were harvested, cells were counted and seeded on the prepared surfaces at $1 \times 10^{5} \mathrm{cells} / \mathrm{sample}$.

An XTT Cell Viability Assay Kit provided a simple method to count live cells using an absorbance reader. The cells' adhesive and repopulative abilities were measured at two early stage time points of $1 \mathrm{~h}$ and $24 \mathrm{~h}$. After the cultured time, the cells on the samples' surface were washed with phosphate-buffered saline (PBS) and transferred to a $200 \mu \mathrm{L}$ culture medium with a $100 \mu \mathrm{L}$ XTT kit and were incubated for another $4 \mathrm{~h}$. The reaction medium was then measured spectrophotometrically at $490 \mathrm{~nm}$ using an ELISA microplate reader UVM-340 (ASYS Hitech GmbH, Eugendorf, Austria). Finally, the cell numbers were determined from a plot of absorbance (OD values) versus the respective E1, 3T3, and
XB-2 cells after adjustment via XTT assays. Each experiment was performed five times $(n=5)$.

After being cultured, the samples were washed and fixed with a mixture of $2 \%$ paraformaldehyde and $2.5 \%$ glutaraldehyde for $2 \mathrm{~h}$. After dehydration in a graded series of ethanol, the samples were treated with iso-amyl acetate and dried using a critical point dryer. The specimens were sputter-coated with gold and the cell morphology was observed using SEM. To compensate for the ion effects in the medium, TTCP was extracted at a ratio of $1 \mathrm{~g}$ TTCP to $10 \mathrm{~mL}$ culture medium. The three cells were cultured in the extraction and on the selected 10/30/TTCP surfaces for $24 \mathrm{~h}$. The statistical analysis was performed using JMP 6.0 software (SAS Institute Inc., Cary, NC, USA) with statistical significance set at $P<0.05$.

\section{Results}

3.1. Topographies and Elements Mapping. The flattest surface was observed in the control group and the etching effects on the Ti surfaces became more significant as the blasting time 


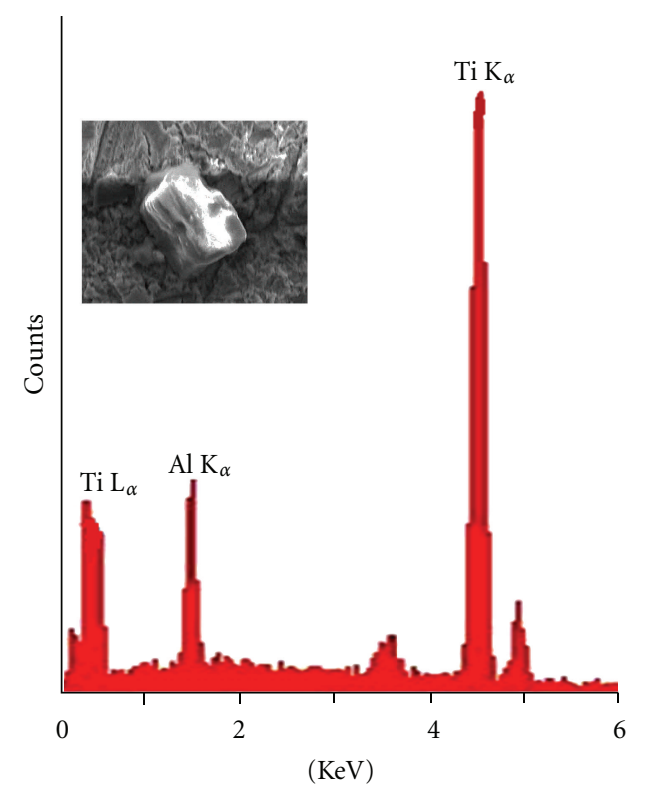

(a)

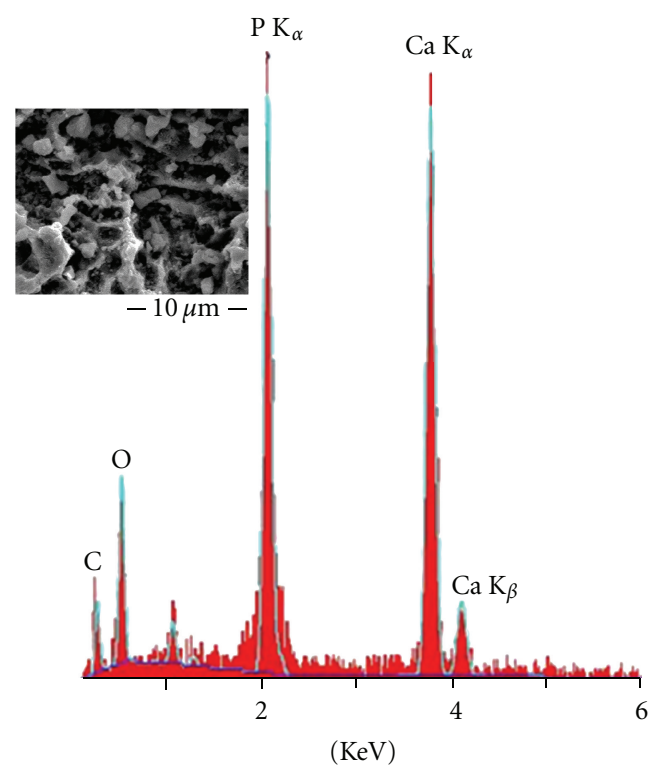

(b)

FIGURE 3: (a) Results of spectrum showing the surfaces having alumina particles in the test groups after 10/30 sec of blasting/etching. (b) EDS showing the surfaces having high levels of $\mathrm{Ca}$ and $\mathrm{P}$ atoms without alumina through secondary blasting of TTCP particles.

was increased in Figures 2(b)-2(d). The SLA 60/30 group obviously increases the roughness more than other groups. $\mathrm{Al}_{2} \mathrm{O}_{3}$ particles are still captured or anchored on the surface even after 5 min ultrasonic cleaning accompanied by $30 \mathrm{sec}$ etching. However, $\mathrm{Al}_{2} \mathrm{O}_{3}$ particles were not found after the secondary grit-blasting using TTCP particles (Figure 3(b)), where only calcium and phosphorus elements were found and reduce the $\mathrm{Ra}$ values in the groups from SLA test group to SLA 10, 30, and 60/30/TTCP (Ra 0.62 $\pm 0.07,0.63 \pm 0.09$, and $0.71 \pm 0.08)$.

3.2. Early Stage Cell Properties. Cells were cultured for $1 \mathrm{~h}$ and $24 \mathrm{~h}$ each to determine their adhesive and initial proliferative abilities. Statistical analysis of all the groups was shown in the Table 1.

Accordingly to the OD values (Figures 4(a) and 4(b)), higher Ra values would reduce the OD values of the E1 and $3 \mathrm{~T} 3$ cells, however, XB-2 cells were unaffected in all measurements. When the cell numbers were aligned and counted after $1 \mathrm{~h}$ (Figure 4(c)), the XB-2 cells on the flattest surface was shown to be four times larger than on the rough SLA 60/30 surface. After $24 \mathrm{~h}, \mathrm{XB}-2$, and 3T3 cells behaved differently depending on the Ra values. As such, the behavior of 3T3 cells was not obviously different after $1 \mathrm{~h}$ and $24 \mathrm{~h}$ of SLA 60/30. The epidermal cells proliferate faster on the rough surface and the fibroblasts displayed a contrary proliferation tendency on a surface with 60/30 SLA treatment, the number of XB-2 cells obtained after $1 \mathrm{~h}$ increased 2.6 times after $24 \mathrm{~h}$ (Table 1).

3.3. Morphologies of Cells. XB-2 and 3T3 cells displayed a round morphology and the filopodia of E1 demonstrated a spider shape originally. The XB-2 and $3 \mathrm{~T} 3$ cells in the control group were spindle-shaped and especial the $\mathrm{XB}$ 2 cells, proliferated on the largest $\mathrm{Ra}$ samples, had an entirely different morphology (Figure 5). The filopodia were extended and evenly distributed over the surface. This phenomenon of altered epithelial morphology is indicating that XB-2 cells have a better growth rate on the rough surface [19].

3.4. Ions Effect. Proliferative patterns of XB-2 and 3T3 cells were no different among SLA 10/30, SLA 10/30/TTCP, and TTCP-extracted medium groups and the conditions of E1 cells deteriorated with anchored SLA 10/30/TTCP group $(P<0.05)$ (Figure 6). However, TTCP-extracted culture medium is basically aid for the E1 early stage proliferation at $24 \mathrm{~h}$ cultured. Hence, in the early stages of cell repopulation, surface conditions are clearly more important for bone cells than the effects of ions.

\section{Discussion}

To view the SLA procedures, $\mathrm{Al}_{2} \mathrm{O}_{3}$ is widely used as sandblasting particles for surface cleaning or developing roughness. These particles, which were entrapped in the $\mathrm{Ti}$ surface, were difficult to remove through a popular used single acid-etching process. Moreover, this has been proved that can cause poor osseointegration, and a high density of $\mathrm{Al}$ ions on the $\mathrm{Ti}$ alloy may be related to Alzheimer's disease [20-22]. Fortunately these particles can be replaced by a secondary sandblasting technique, which has a smaller particle size distribution than $\mathrm{Al}_{2} \mathrm{O}_{3}$. 


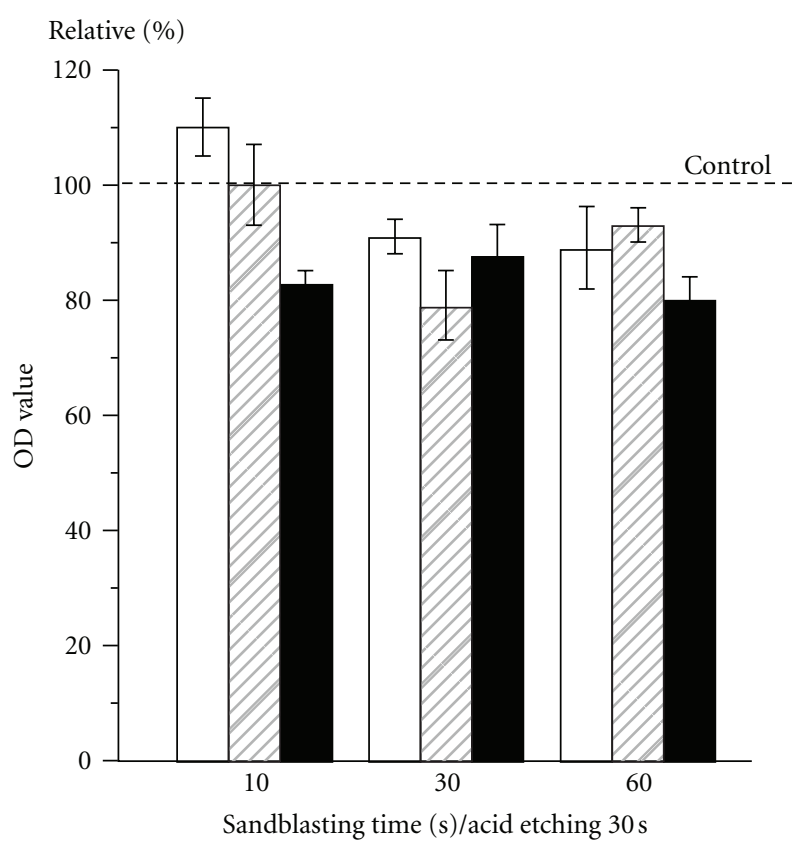

(a)

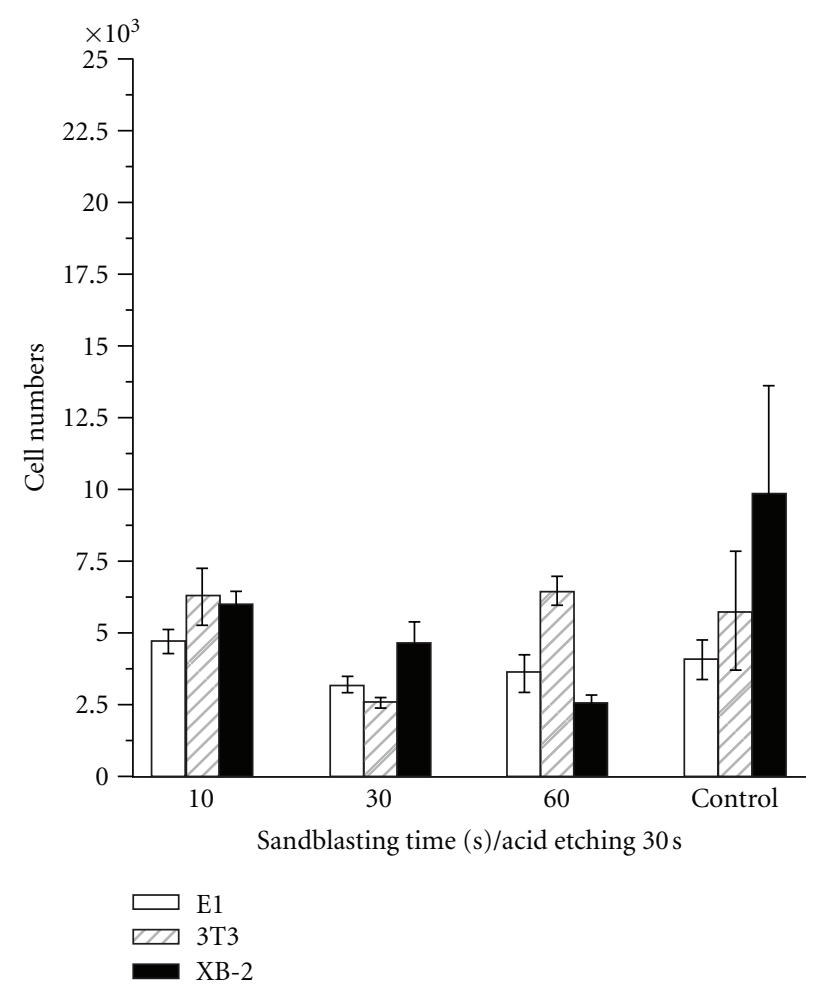

(c)

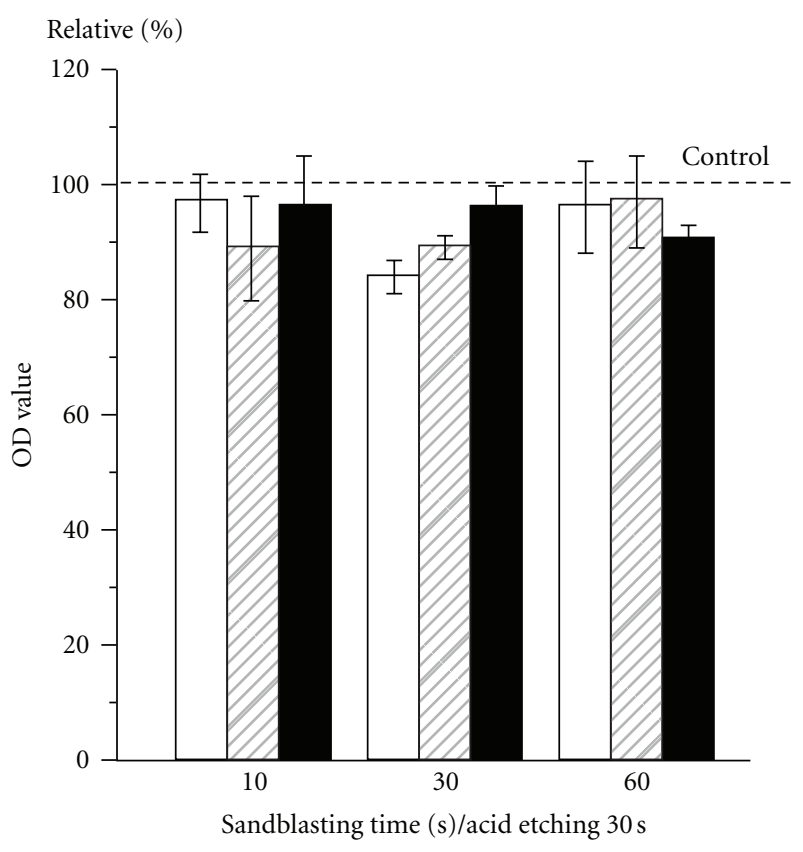

(b)

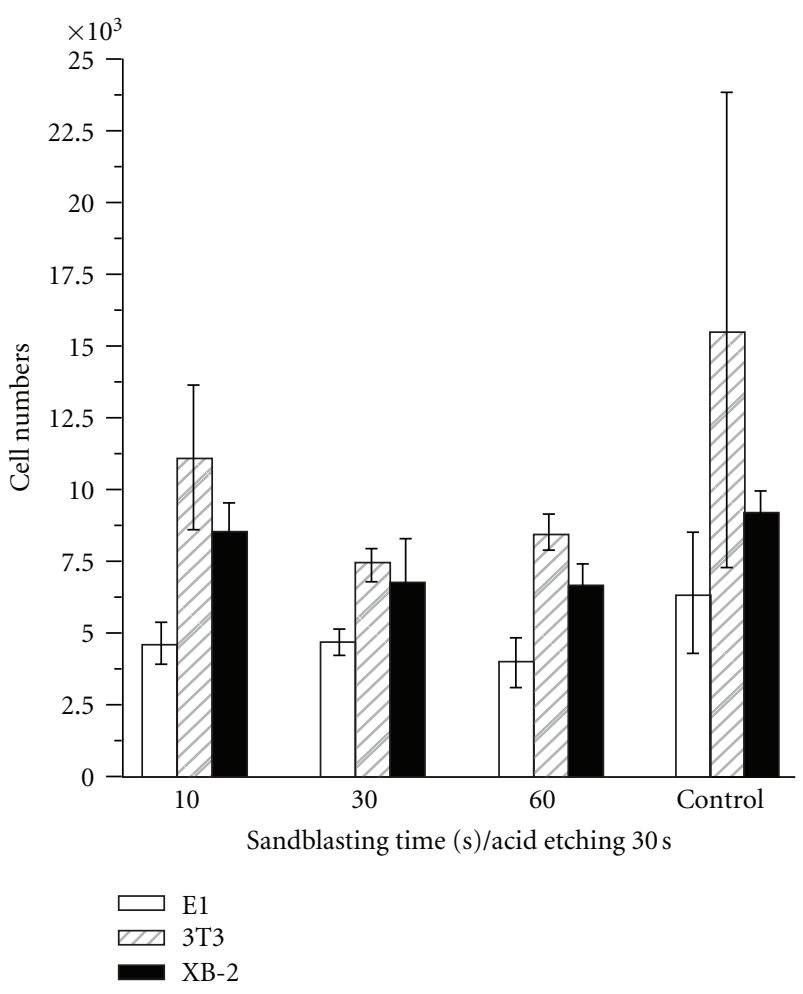

(d)

FIGURE 4: Different cells cultured on a variety of topographies: OD values after (a) $1 \mathrm{~h}$ of adhesion and (b) $24 \mathrm{~h}$ of proliferation were compared with the control group and the cell numbers were counted after $1 \mathrm{~h} \mathrm{(c)} \mathrm{and} 24 \mathrm{~h} \mathrm{(d).}$

After placement of the dental implant, the complications of infection and fibrous encapsulation may occur during the healing process. The success of dental implants cannot merely be defined by the efficacy of osseointegration between the bone and the implant. Rather, a proper biological interaction to obtain healthy gingiva is essential as shown in Figure 1. Among both of these contact parts between the tissues and the implant, epithelium linking would lead to the absence of inflammation [14]. The integration of soft tissue provides a beneficial strategy where the epithelium linking is 


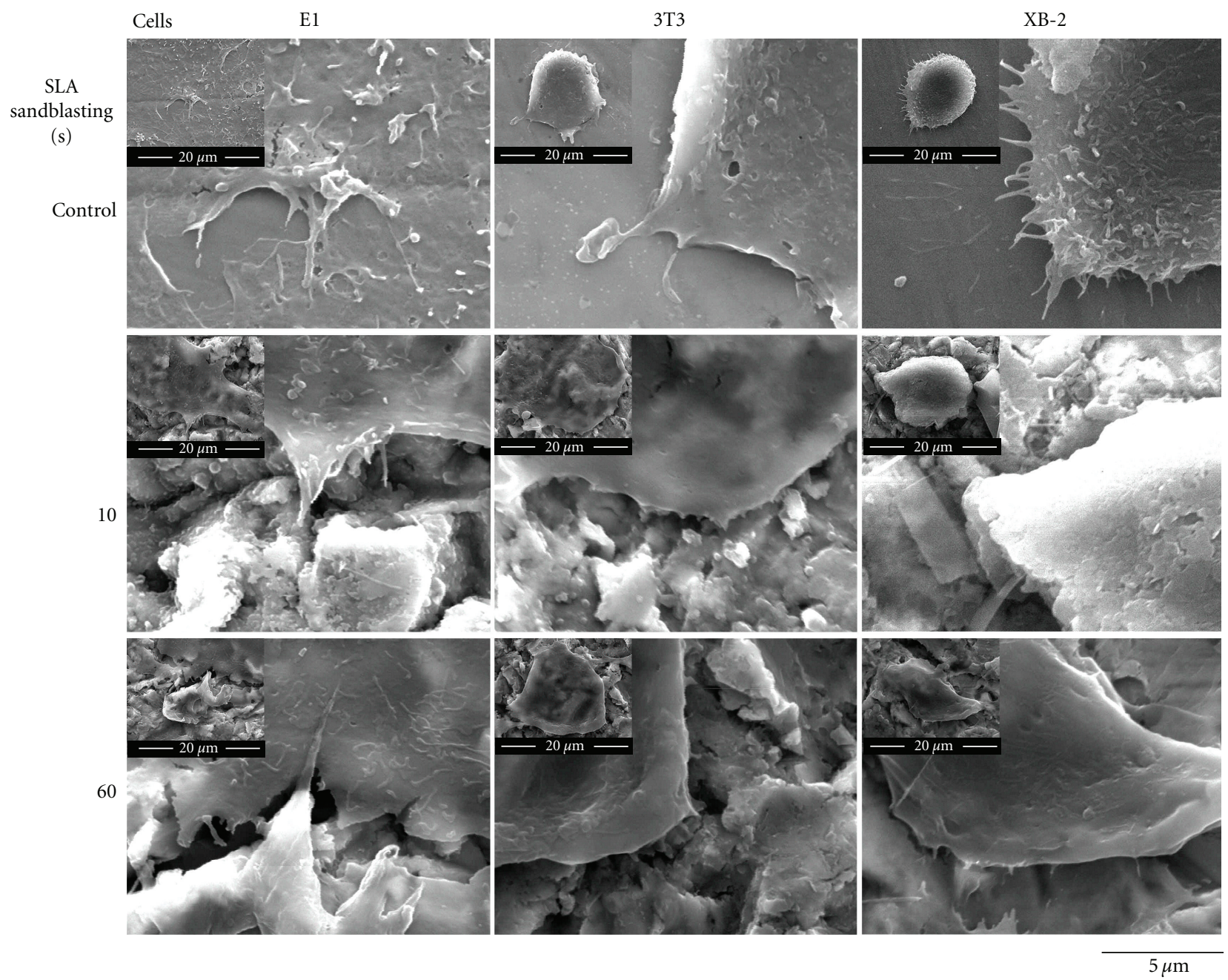

FIGURE 5: SEM images showing the proliferative morphologies of the various cells growing on areas of varying roughness in the control and test groups after 10, 30, and 60/30 sec of blasting and etching after $24 \mathrm{~h}$.

enhanced while the contact part of the gingival connective tissues is suppressed.

Unlike the case with their early stage adhesive and proliferative behavior, the XB-2 and 3T3 cells acted differently than each other in respect to their reaction to surface roughness. Based on the analysis in Figures 4(c) and 4(d), 3T3 cells cultured on the smooth surface of the control group after $1 \mathrm{~h}$ were not significantly different from the largest roughness SLA 60/30 testing group (Table 1). However, in the control group, after $24 \mathrm{~h}$ cultured, the $3 \mathrm{~T} 3$ cells went largely beyond testing groups with rough surfaces and were a 2.7 -fold increase in cell numbers at $1 \mathrm{~h}$ culturing. Contrary to the results obtained with the $3 \mathrm{~T} 3$ cells, the XB-2 cells had a statistical significance in roughness after $1 \mathrm{~h}$ of culturing; the control group displayed the best cell adhesive ability. However, after the XB-2 cells were allowed to proliferate at early stage for $24 \mathrm{~h}$, there were no significant differences between the control and test groups $(P>0.05)$. This early stage result indicates that epithelial cells cultured on roughened surfaces have better proliferative abilities than those cultured on smooth surfaces. The proliferative rate of
XB-2 cells increased 2.6-fold from $1 \mathrm{~h}$ to $24 \mathrm{~h}$ of culturing for the SLA 60/30 testing, though the control group showed no specific statistical change. XB-2 cell's qualities in the control group after $1 \mathrm{~h}$ culturing were better than those of the roughened surfaces, the proliferative properties after $24 \mathrm{~h}$ culturing were reversed.

Early stage cell abilities such as adhesion and proliferation to the substrates can vary according to surface topography, which in turn influences cytoskeletal components [19, 23]. Sandblasting was thought to induce stress on the surface, whereas acid etching was thought to release the resulting residual stresses. Several related experiments [16, 24-26] reported that surface conditions can affect different types of cell morphology, and this is referred to as cell-specific discrepancies [27]. Surface characteristics have been shown to regulate how the different cells reach clinically appropriate proportions with respect to the implant. For example, one of the main challenges in implant treatment lies in achieving an esthetic appearance, involving a physiological outcome [2830]. For soft-tissue integration involving epithelium cells adhesion and proliferation, roughened topographies should 
TABLE 1: One-way ANOVA statistical analysis of the control group $(0 \mathrm{sec})$ and test groups using 30 sec of acid etching after 10, 30, and 60 sec of sandblasting for samples from bone E1, fibroblast 3T3, and an epidermal cell XB-2 cells after 1 and $24 \mathrm{~h}(n=5)$.

(a)

\begin{tabular}{|c|c|c|c|c|c|c|c|c|c|}
\hline \multirow{2}{*}{$\begin{array}{l}\text { Statistical } \\
\text { analysis* }\end{array}$} & \multirow{2}{*}{ Variations } & \multicolumn{8}{|c|}{ Time of sandblasting (sec) } \\
\hline & & \multicolumn{2}{|r|}{$0^{\mathrm{b}}$} & \multicolumn{2}{|r|}{10} & \multicolumn{2}{|r|}{30} & \multicolumn{2}{|c|}{60} \\
\hline Groups & Cells & $P$ value & $\begin{array}{c}\text { Group } \\
\text { comparisons }^{\mathrm{a}}\end{array}$ & $P$ value & $\begin{array}{c}\text { Group } \\
\text { comparisons }\end{array}$ & $P$ value & $\begin{array}{c}\text { Group } \\
\text { comparisons }\end{array}$ & $P$ value & $\begin{array}{c}\text { Group } \\
\text { comparisons }\end{array}$ \\
\hline $\begin{array}{l}1 \mathrm{~h} \text { cell } \\
\text { adhesion }\end{array}$ & 3T3/E1/XB-2 & 0.0161 & $\mathrm{XB}-2>\mathrm{E} 1$ & 0.0077 & $\begin{array}{c}3 \mathrm{~T} 3>\mathrm{E} 1 \\
\mathrm{XB}-2>\mathrm{E} 1\end{array}$ & 0.0013 & $\begin{array}{c}\mathrm{XB}-2>\mathrm{E} 1 \\
\mathrm{XB}-2>3 \mathrm{~T} 3\end{array}$ & $<0.0001$ & $\begin{array}{c}3 \mathrm{~T} 3>\mathrm{E} 1 \\
3 \mathrm{~T} 3>\mathrm{XB}-2 \\
\mathrm{XB}-2>\mathrm{E} 1\end{array}$ \\
\hline $\begin{array}{l}24 \mathrm{~h} \text { cell } \\
\text { proliferation }\end{array}$ & 3T3/E1/XB-2 & 0.0705 & none & 0.0026 & $\begin{array}{c}3 \mathrm{~T} 3>\mathrm{E} 1 \\
\mathrm{XB}-2>\mathrm{E} 1\end{array}$ & 0.0231 & $\mathrm{XB}-2>\mathrm{E} 1$ & $<0.0001$ & $\begin{array}{c}3 \mathrm{~T} 3>\mathrm{E} 1 \\
3 \mathrm{~T} 3>\mathrm{XB}-2 \\
\mathrm{XB}-2>\mathrm{E} 1\end{array}$ \\
\hline
\end{tabular}

(b)

\begin{tabular}{|c|c|c|c|c|c|c|c|}
\hline $\begin{array}{l}\text { Statistical } \\
\text { analysis* }\end{array}$ & Variations & \multicolumn{2}{|c|}{ E1 bone cell } & \multicolumn{2}{|c|}{ 3T3 fibroblast cell } & \multicolumn{2}{|c|}{ XB-2 epidermal cell } \\
\hline Groups & $\begin{array}{c}0 \mathrm{sec}^{\mathrm{b}} \text { and through } 30 \mathrm{sec} \\
\text { etching after } 10,30 \text {, and } \\
60 \mathrm{sec} \text { blasting }\end{array}$ & $P$ value & $\begin{array}{c}\text { Group } \\
\text { comparisons }^{\mathrm{a}}\end{array}$ & $P$ value & $\begin{array}{c}\text { Group } \\
\text { comparisons }^{\mathrm{a}}\end{array}$ & $P$ value & $\begin{array}{c}\text { Group } \\
\text { comparisons }^{\mathrm{a}}\end{array}$ \\
\hline $\begin{array}{l}1 \mathrm{~h} \text { cell } \\
\text { adhesion }\end{array}$ & $0 / 10 / 30 / 60$ & 0.0025 & $30>0,10,60$ & 0.0026 & $\begin{array}{l}10>30 \\
60>10\end{array}$ & 0.0005 & $\begin{array}{c}0>10,30,60 \\
10>60\end{array}$ \\
\hline $\begin{array}{l}24 \mathrm{~h} \text { cell } \\
\text { proliferation }\end{array}$ & $0 / 10 / 30 / 60$ & 0.0510 & none & 0.0791 & none & 0.2788 & none \\
\hline
\end{tabular}

${ }^{*}$ Groups significantly differ at $P<0.05$; "none" indicates the group comparisons are not significantly different at $P>0.05$; " 0 sec" indicates the control group without the blasting/etching treatment.

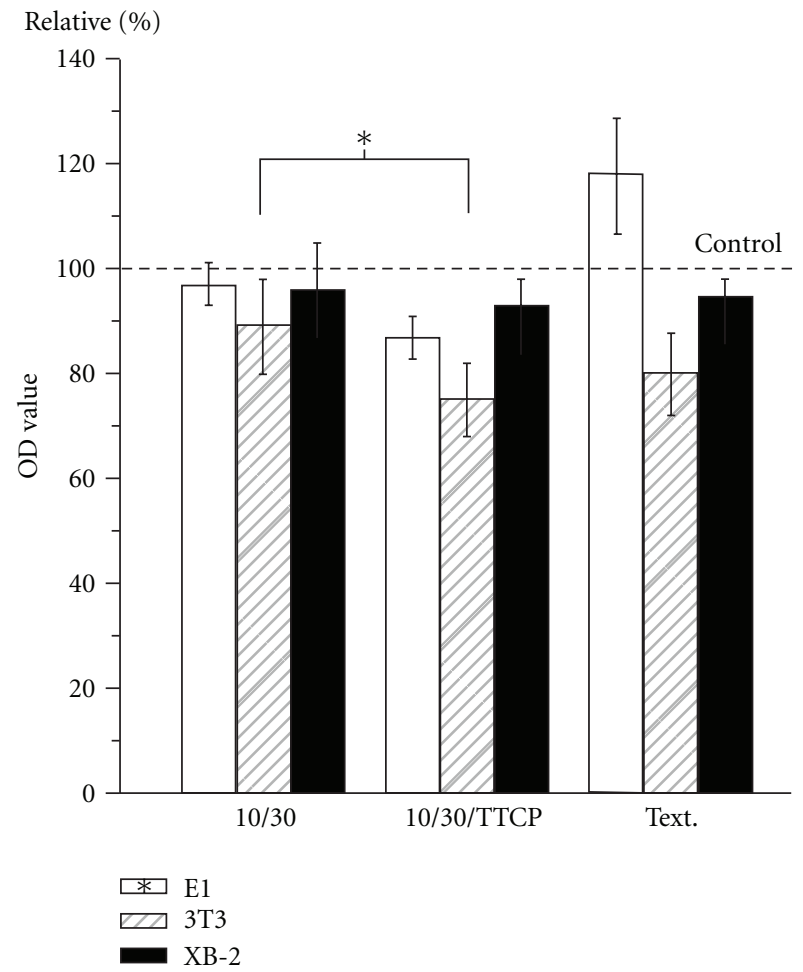

FIgURE 6: A diagram indicating the OD values after $24 \mathrm{~h}$ cell proliferations of the test groups: SLA 10/30, 10/30/TTCP and TTCP extraction cells culture medium (Text.) $\left(^{*}\right.$ : a statistically significant difference in the group comparisons, $P<0.05)$. be recommended, as they can increase linking and inhibit the risk of fibrous capsulation by connective tissues.

The ion effects are demonstrated in Figure 6. The early stage cell proliferative ability in the extracted cultured medium was significantly increased $(P<0.05)$ in E1 cells but decreased in 3T3 cells. However, when the ionic effect was combined with the effect of topography in the comparative SLA 10/30/TTCP group, the proliferative ability of E1 cells was shown to be significant lower $(P<0.05)$ than in the SLA 10/30 group. The calcium and phosphate ions became incorporated into the apatite that formed in an intimate association with the organic component, leading to bone formation [31, 32]. Figure 6 showed the promoted E1 bone cell growth was largely due to the topography rather than the ions. The ion effect played a less important role than the roughness with respect to E1 cell proliferation. The existence of calcium phosphates in a thin film coating can play a mediatory role between implants and natural bone tissues, but such properties did not lead to clinical success $[33,34]$. Rough surfaces enhanced the ability to act as essential factors for bone cell adhesion and proliferation. The contacting surfaces between implants and the soft tissues should be roughened and ions releasing from TTCP hydrolysis should also be commented. This study clearly confirms the hypothesis that roughness and ion effects would impact the initial implant stability by the early stage cell interactions. The results had demonstrated that TTCP as the ions releasing medium could be a potential application in bone regeneration and prevention of the fibrous encapsulation of implants. 


\section{Conclusions}

Techniques necessary to harmonize the early stage adhesion and proliferation of osteoblasts and epithelial cells on the implant are important. The optimal implant can be designed with a smooth surface in the top area of implant, which is closer to the gingival surface, to promote rapid epithelial cell adhesion that could lead to prevent inflammation after implantation. A rougher surface anchored with TTCP can replace $\mathrm{Al}_{2} \mathrm{O}_{3}$ particles in the sandblasting process and provide soluble ions to enhance the early stage proliferation of osteoblast cells. Such results suggest that an active surface can be prepared to achieve appropriate implant biological widths. In summary, we emphasize a concept whereby an implant actively regulates cells rather than undergoing a passive healing process, at the same time eliminating the dangers of fibrous encapsulation at an early implant stage.

\section{Acknowledgments}

Financial support was received via Grants from Kaohsiung Medical University Research Foundation and Taiwan and Kaohsiung Medical Device Special Zone in Southern Taiwan Science Park, under Contracts Q098001 and CZ-02-07-2298 , respectively. This financial support is greatly appreciated. W.-C. Chen contributed equally to this work as first authors.

\section{References}

[1] K. Kieswetter, Z. Schwartz, D. D. Dean, and B. D. Boyan, "The role of implant surface characteristics in the healing of bone," Critical Reviews in Oral Biology and Medicine, vol. 7, no. 4, pp. 329-345, 1996.

[2] H. P. Weber and D. L. Cochran, "The soft tissue response to osseointegrated dental implants," Journal of Prosthetic Dentistry, vol. 79, no. 1, pp. 79-89, 1998.

[3] R. Glauser, P. Schupbach, J. Gottlow, and C. H. F. Hammerle, "Soft Tissue Integration of a TiUnite implant. The image shows junctional epithelium at the implant surface and a shallow sulcus lined by sulcular epithelium," Clinical Implant Dentistry and Related Research, vol. 7, supplement 1, pp. 4451, 2005.

[4] I. Abrahamsson, T. Berglundh, J. Wennström, and J. Lindhe, "The peri-implant hard and soft tissues at different implant systems: a comparative study in the dog," Clinical Oral Implants Research, vol. 7, no. 3, pp. 212-219, 1996.

[5] I. Abrahamsson, T. Berglundh, P. O. Glantz, and J. Lindhe, "The mucosal attachment at different abutments: an experimental study in dogs," Journal of Clinical Periodontology, vol. 25, no. 9, pp. 721-727, 1998.

[6] D. C. Smith, "Dental implants: materials and design considerations," The International Journal of Prosthodontics, vol. 6, no. 2, pp. 106-117, 1993.

[7] L. Le Guehennec, A. Soueidan, P. Layrolle, and Y. Amouriq, "Surface treatments of titanium dental implants for rapid osseointegration," Dental Materials, vol. 23, no. 7, pp. 844$854,2007$.

[8] A. B. Novaes, V. Papalexiou Jr., M. F. Grisi, S. S. Souza, M. Taba, and J. K. Kajiwara, "Influence of implant microstructure on the osseointegration of immediate implants placed in periodontally infected sites: a histomorphometric study in dogs," Clinical Oral Implants Research, vol. 15, no. 1, pp. 3443, 2004

[9] C. M. Stanford, "Surface modification of biomedical and dental implants and the processes of inflammation, wound healing and bone formation," International Journal of Molecular Sciences, vol. 11, no. 1, pp. 354-369, 2010.

[10] D. L. Cochran, R. K. Schenk, A. Lussi, F. L. Higginbottom, and D. Buser, "Bone response to unloaded and loaded titanium implants with a sandblasted and acid-etched surface: a histometric study in the canine mandible," Journal of Biomedical Materials Research, vol. 40, no. 1, pp. 1-11, 1998.

[11] M. Browne and P. J. Gregson, "Effect of mechanical surface pretreatment on metal ion release," Biomaterials, vol. 21, no. 4, pp. 385-392, 2000.

[12] C. Aparicio, F. Javier Gil, C. Fonseca, M. Barbosa, and J. A. Planell, "Corrosion behaviour of commercially pure titanium shot blasted with different materials and sizes of shot particles for dental implant applications," Biomaterials, vol. 24, no. 2, pp. 263-273, 2003.

[13] S. Szmukler-Moncler, D. Perrin, V. Ahossi, G. Magnin, and J. P. Bernard, "Biological properties of acid etched titanium implants: effect of sandblasting on bone anchorage," Journal of Biomedical Materials Research: Part B, vol. 68, no. 2, pp. 149159, 2004.

[14] M. A. Listgarten, "Soft and hard tissue response to endosseous dental implants," Anatomical Record, vol. 245, no. 2, pp. 410425, 1996.

[15] C. Blaschke and U. Volz, "Soft and hard tissue response to zirconium dioxide dental implants—a clinical study in man," Neuroendocrinology Letters, vol. 27, supplement 1, pp. 69-72, 2006.

[16] D. W. Hamilton, B. Chehroudi, and D. M. Brunette, "Comparative response of epithelial cells and osteoblasts to microfabricated tapered pit topographies in vitro and in vivo," Biomaterials, vol. 28, no. 14, pp. 2281-2293, 2007.

[17] N. Eidelman, L. C. Chow, and W. E. Brown, "Calcium phosphate phase transformations in serum," Calcified Tissue International, vol. 41, no. 1, pp. 18-26, 1987.

[18] K. L. Blacker, M. L. Williams, and M. Goldyne, "Mitomycin C-treated 3T3 fibroblasts used as feeder layers for human keratinocyte culture retain the capacity to generate eicosanoids," Journal of Investigative Dermatology, vol. 89, no. 6, pp. 536539, 1987.

[19] M. Di Carmine, P. Toto, C. Feliciani et al., "Spreading of epithelial cells on machined and sandblasted titanium surfaces: an in vitro study," Journal of Periodontology, vol. 74, no. 3, pp. 289-295, 2003.

[20] Y. S. Chang, M. Oka, M. Kobayashi et al., "Significance of interstitial bone ingrowth under load-bearing conditions: a comparison between solid and porous implant materials," Biomaterials, vol. 17, no. 11, pp. 1141-1148, 1996.

[21] A. Ignatius, M. Peraus, S. Schorlemmer et al., "Osseointegration of alumina with a bioactive coating under load-bearing and unloaded conditions," Biomaterials, vol. 26, no. 15, pp. 2325-2332, 2005.

[22] W. C. Chen, C. P. Ju, Y. C. Tien, and J. H. C. Lin, "In vivo testing of nanoparticle-treated TTCP/DCPA-based ceramic surfaces," Acta Biomaterialia, vol. 5, no. 5, pp. 1767-1774, 2009.

[23] F. Rupp, L. Scheideier, N. Olshanska, M. de Wild, M. Wieland, and J. Geis-Gerstorfer, "Enhancing surface free energy and hydrophilicity through chemical modification of microstructured titanium implant surfaces," Journal of 
Biomedical Materials Research: Part A, vol. 76, no. 2, pp. 323334, 2006.

[24] D. M. Brunette, "Fibroblasts on micromachined substrata orient hierarchically to grooves of different dimensions," Experimental Cell Research, vol. 164, no. 1, pp. 11-26, 1986.

[25] D. M. Brunette, "In vitro models of biological responses to implants," Advances in Dental Research, vol. 13, pp. 35-37, 1999.

[26] S. A. Biela, Y. Su, J. P. Spatz, and R. Kemkemer, "Different sensitivity of human endothelial cells, smooth muscle cells and fibroblasts to topography in the nano-micro range," Acta Biomaterialia, vol. 5, no. 7, pp. 2460-2466, 2009.

[27] M. M. Stevens and J. H. George, "Exploring and engineering the cell surface interface," Science, vol. 310, no. 5751, pp. 1135$1138,2005$.

[28] L. C. Chow, M. Markovic, S. A. Frukhtbeyn, and S. Takagi, "Hydrolysis of tetracalcium phosphate under a near-constantcomposition condition-effects of $\mathrm{pH}$ and particle size," Biomaterials, vol. 26, no. 4, pp. 5393-5401, 2005.

[29] Y. Oshida, E. B. Tuna, O. Aktören, and K. Gençay, "Dental implant systems," International Journal of Molecular Sciences, vol. 11, no. 4, pp. 1580-1678, 2010.

[30] R. M. Wazen, L. P. Lefebvre, E. Baril, and A. Nanci, "Initial evaluation of bone ingrowth into a novel porous titanium coating," Journal of Biomedical Materials Research, vol. 94, no. 1, pp. 64-71, 2010.

[31] L. Fassina, E. Saino, M. G. Cusella De Angelis, G. Magenes, F. Benazzo, and L. Visai, "Low-power ultrasounds as a tool to culture human osteoblasts inside cancellous hydroxyapatite," Bioinorganic Chemistry and Applications, vol. 2010, Article ID 456240, 2010.

[32] S. Raynaud, E. Champion, D. Bernache-Assollant, and P. Thomas, "Calcium phosphate apatites with variable $\mathrm{Ca} / \mathrm{P}$ atomic ratio I. Synthesis, characterisation and thermal stability of powders," Biomaterials, vol. 23, no. 4, pp. 1065-1072, 2002.

[33] J. E. Davies, "Understanding peri-implant endosseous healing." Journal of Dental Education, vol. 67, no. 8, pp. 932-949, 2003.

[34] J. E. Ellingsen, P. Thomsen, and S. P. Lyngstadaas, "Advances in dental implant materials and tissue regeneration," Periodontology, vol. 41, no. 1, pp. 136-156, 2000. 


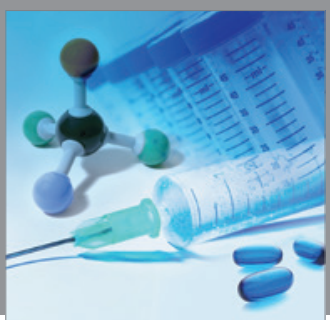

International Journal of

Medicinal Chemistry

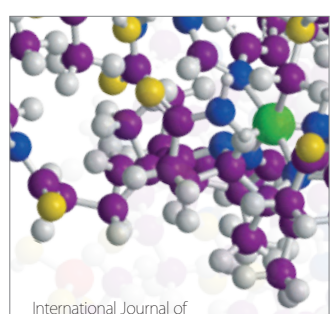

Carbohydrate Chemistry

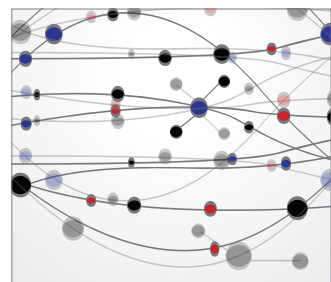

The Scientific World Journal
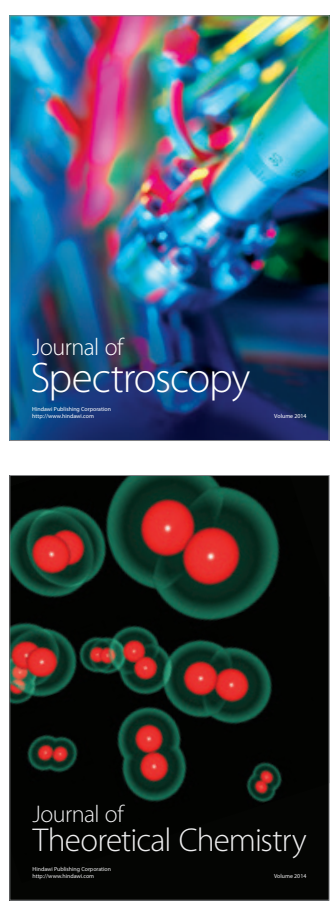
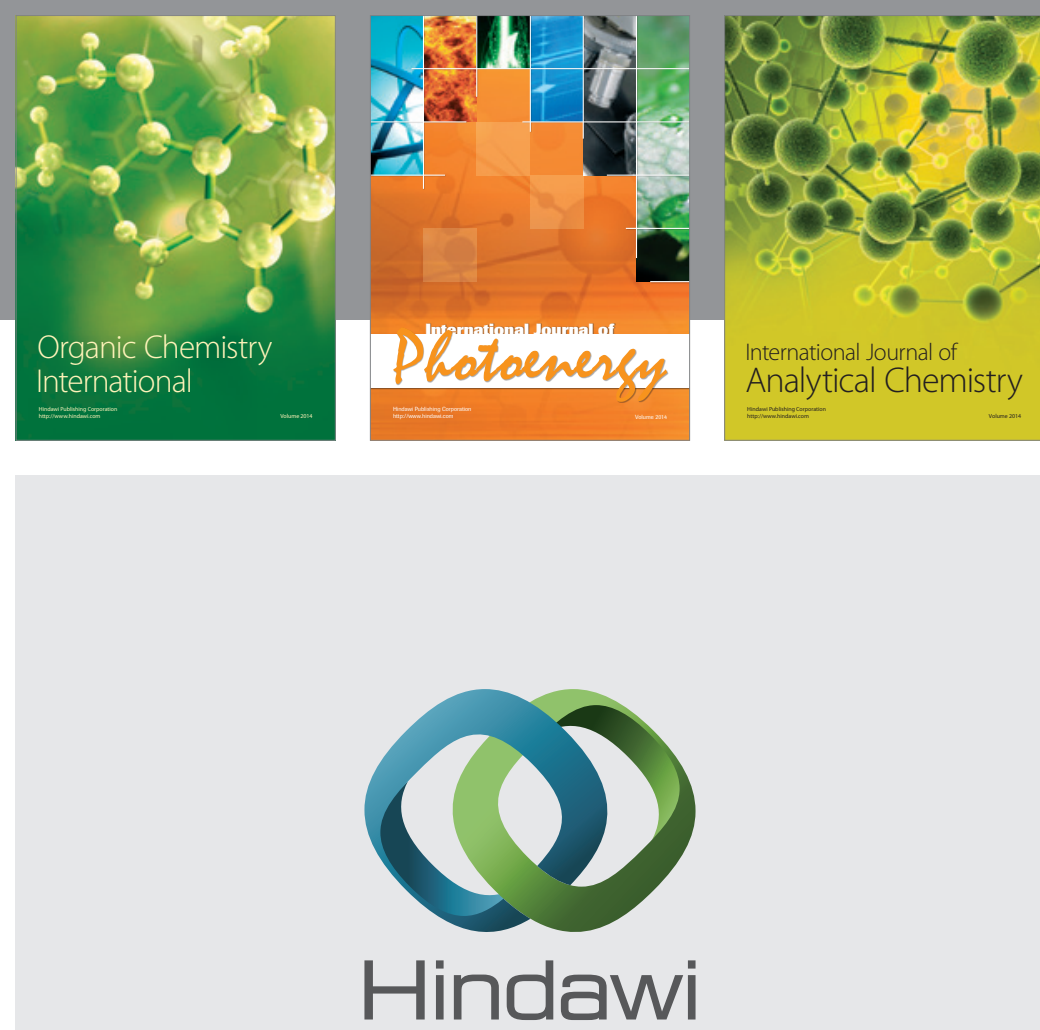

Submit your manuscripts at

http://www.hindawi.com
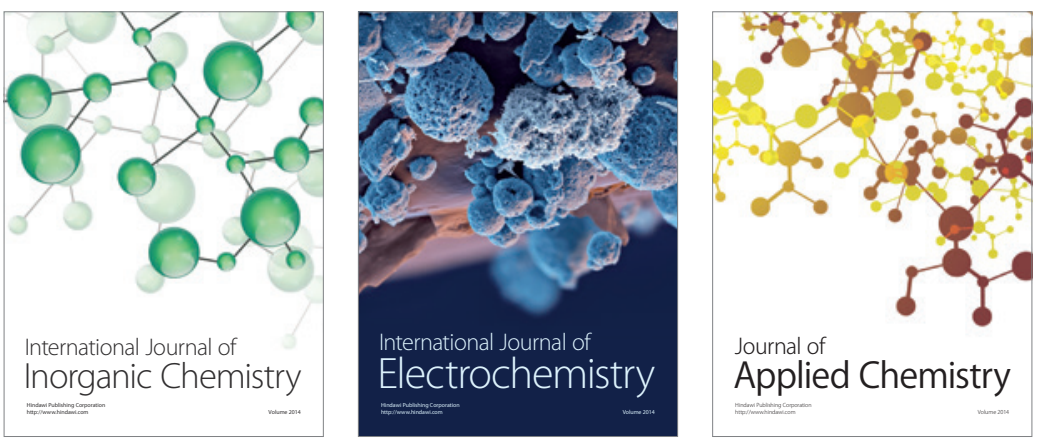

Journal of

Applied Chemistry
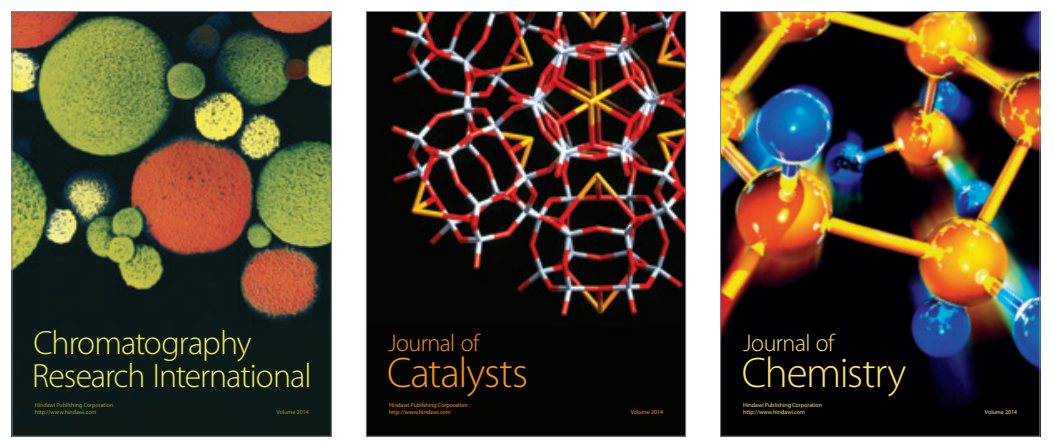
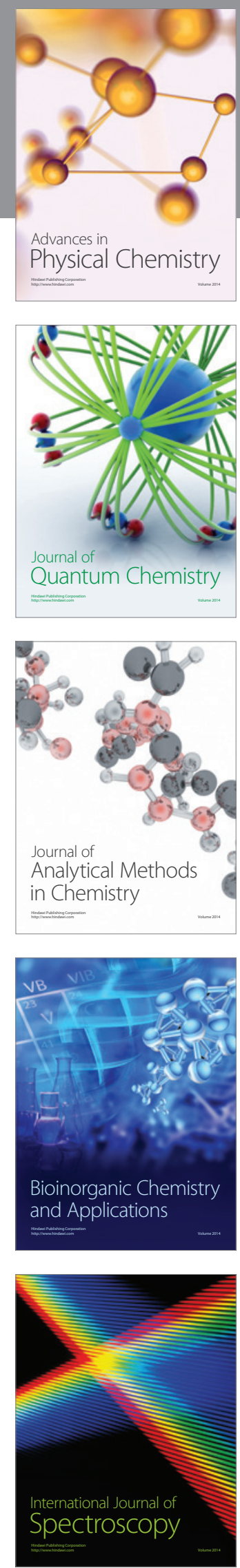